\title{
PENGARUH MEDIA PEMBELAJARAN DAN KEMANDIRIAN \\ BELAJAR TERHADAP HASIL BELAJAR IPA SISWA KELAS IV SEKOLAH DASAR
}

\author{
Siska Oktavera \\ Guru Sekolah Dasar Karang Tengah Tangerang \\ Siska_Okta@yahoo.com
}

\begin{abstract}
This study aims to determine the effect of the learning media that include video and picture media and self-regulated learning of the learning outcomes of Natural Science on the content correlation between of natural resource with environment and technology. The study was conducted on students in grade IV SD Negeri Karang Tengah 4 Tangerang, the number of students as many as 36 students. Research using experiment method treatment by level 2 x 2 . Data analysis is the analysis of variance of two path (ANOVA). The result of this study indicate that (1) There are differences in learning outcomes of natural science among the group given video media and the group given picture media (2) there are interaction between learning media with self-regulated of the learning outcomes of natural science on the content correlation between of natural resource with environment and technology.
\end{abstract}

Keywords: video media, picture media, self-regulated learning, learning outcomes of natural science.

\begin{abstract}
Abstrak: Penelitian ini bertujuan untuk Tentukan pengaruh media pembelajaran yang meliputi media video dan gambar dan pembelajaran mandiri dari hasil belajar Ilmu Pengetahuan Alam pada korelasi antara isi dari sumber daya alam dengan lingkungan dan teknologi. Penelitian dilakukan pada siswa kelas IV Sekolah Dasar Karang Tengah 4 Tangerang, jumlah siswa sebanyak 36 siswa. Penelitian menggunakan metode eksperimen pengobatan oleh tingkat $2 \times 2$. Analisis data adalah analisis varians dua jalur (ANOVA). Hasil penelitian ini menunjukkan bahwa (1) Ada perbedaan hasil belajar ilmu pengetahuan alam antara media video grup tertentu dan kelompok yang diberi Media gambar (2) ada interaksi antara media pembelajaran dengan mandiri dari hasil belajar alam ilmu tentang korelasi antara isi dari sumber daya alam dengan lingkungan dan teknologi.
\end{abstract}

Kata kunci: media video, media gambar, pembelajaran mandiri, hasil belajar ilmu pengetahuan alam.

Sesuai dengan Peraturan Pemerintah Nomor

19 Tahun 2005 tentang Standar Nasional

Pendidikan, salah satu standar yang harus

dikembangkan adalah Standar Proses. Standar

Proses adalah standar nasional pendidikan yang berkaitan dengan pelaksanaan pembelajaran pada satuan pendidikan untuk mencapai kompetensi lulusan. Secara umum, permasalahan yang sering kali terjadi dalam dunia pendidikan, khususnya pendidikan 
sekolah dasar adalah hasil belajar siswa yang rendah. Menurut Sudjana (2011: 22), hasil belajar adalah semua kemampuankemampuan yang dimiliki siswa setelah ia menerima pengalaman belajarnya.

Hasil belajar siswa yang rendah dapat diketahui dengan melihat hasil belajar siswa yang tidak sedikit mendapatkan nilai di bawah kriteria ketuntasan minimal (KKM). Kenyataan ini mengisyaratkan bahwa pengetahuan siswa terhadap kompetensi dasar yang diberikan masih dalam tahap rendah. Salah satu dari beberapa mata pelajaran yang dibelajarkan di Sekolah Dasar (SD) adalah mata pelajaran Ilmu Pengetahuan Alam (IPA).

IPA merupakan salah satu mata pelajaran yang dekat dengan kehidupan sehari-hari, mulai dari membuka mata di pagi hari hingga beristirahat di malam hari. Oleh sebab itulah IPA merupakan salah satu mata pelajaran penting yang dibelajarkan di sekolah dasar. Menurut Cahyo (2013: 212213) pada prinsipnya, pembelajaran IPA bukan hanya penyampaikan kumpulan pengetahuan yang berupa fakta-fakta, konsepkonsep, prinsip-prinsip atau penyampaian materi abstrak saja, akan tetapi pembelajaran IPA merupakan suatu proses penemuan pengetahuan, pembentukan sikap ilmiah, juga kemampuan untuk menerapkan prinsip- prinsip IPA itu sendiri ke dalam kehidupan sehari-hari.

Sesuai pada hasil wawancara dengan kedua guru kelas IV SD Negeri Karang Tengah 4 Tangerang yang memiliki 35 siswa di kelas A dan 35 siswa di kelas B, serta melihat dan menghitung data yang diberikan, diperoleh penjelasan bahwa hasil belajar disetiap ulangan harian tahun ajaran 20142015 yang menerapkan kurikulum 2013, hasil belajar siswa kelas IV SD Negeri Karang Tengah 4 Tangerang cukup memprihatinkan. Selain mengalami penurunan hasil belajar disetiap ulangan hariannya, $70 \%$ siswa mendapatkan nilai dibawah 55 pada hasil belajar ulangan harian yang diadakan. Gejala ini tidak hanya terjadi di salah satu kelas IV saja, namun di kelas IV lainnya pun terjadi masalah yang sama.

Melihat mundur ke tahun ajaran 20132014 yang masih membedakan mata pelajaran IPA dengan mata pelajaran lainnya, ternyata mengalami permasalahan yang tidak jauh berbeda dengan siswa ditahun ajaran yang sedang berlangsung, siswa kelas IV yang kini sudah berada di kelas V pun sebelumnya mengalami hal yang sama saat berada di kelas IV kemarin, khususnya pada mata pelajaran IPA. $45 \%$ siswa tidak mencapai KKM pada mata pelajaran IPA yang berjumlah 75 pada tahun ajaran 2013-2014 yang lalu. Hal ini sangat jelas menunjukan pengetahuan siswa 
terhadap kompetensi dasar IPA yang diberikan masih dalam tahap rendah.

Untuk menambah pengetahuan siswa, guru pun sering memberi tugas untuk mengulang materi yang sudah diajarkan di rumah, atau dengan meminta siswa untuk menonton film atau vidio yang ada di tv atau internet yang kini sudah mengalami kemajuan dalam hal membantu memberikan pengetahuan bagi pendidikan. Hal ini sangat membantu menambah pengetahuan bagi siswa yang mau melaksanakan tugas dari gurunya, tapi tidak bagi siswa yang hanya mau menerima materi yang diberikan di sekolah tanpa berusaha untuk menambah pengetahuannya dari luar sekolah.

Terkait kenyataan yang dijelaskan di atas, banyak hal buruk yang akan terjadi jika kondisi tersebut tetap dibiarkan tanpa mencari tahu solusi penyelesaiannya. Selain pembelajaran yang sudah dilakukan susah payah menjadi sia-sia tanpa mencapai tujuan yang diinginkan, siswa pun akan sulit untuk mencapai nilai KKM di ujian akhir kenaikan kelas yang berujung tidak bisa naik kelas. maka dari itu, penting untuk mengetahui apa saja yang menjadi penyebab dan yang pempengaruhi rendahnya hasil belajar.

Cronbach (1984: 231) berpendapat bahwa "Learning is shown by a change in behavior as a result of experience". Yang artinya belajar ditunjukkan oleh perubahan perilaku sebagai hasil dari pengalaman. Dengan proses belajar yang berkualitas maka akan menghasilkan hasil belajar yang diinginkan. Menurut Hamalik (2011: 50-53) alat bantu belajar atau media termasuk dalam unsur dalam proses belajar yang memiliki sifat dinamis yang sewaktu-waktu dapat berubah-ubah, kadang menguat kadang melemah yang dapat mempengaruhi proses belajar yang berkaitan dengan pelaksanaan pembelajaran untuk mencapai kompetensi lulusan dengan hasil belajar yang diinginkan.

Jika dilihat dari sisi teori belajar, penjelasan unsur tersebut mendekati paham dengan teori belajar pemrosesan informasi. Dimana teori pemrosesan informasi ini menurut Yudhawati dan Haryanto (2011: 45) menjelaskan bahwa di dalam pemrosesan informasi terjadi adanya interaksi antara kondisi-kondisi internal dan kondisi-kondisi ekternal pada tiap individu. Keadaan dari dalam diri seseorang yang mengingkinkan pencapaian hasil belajar yang tinggi itulah yang disebut dengan kondisi internal. Sedangkan rangsangan-rangsangan yang mempengaruhi seseorang dari lingkungannya dalam proses pembelajaran merupakan kondisi eksternal.

Selain itu, penjelasan di atas pun menurut Rusman (2012: 104-106) berkaitan dengan implikasi prinsip-prinsip belajar bagi siswa yang tidak dapat diabaikan begitu saja 
selama proses pembelajaran berlangsung, Seperti prinsip yang pertama yaitu perhatian dan motivasi, dimana dalam proses pembelajaran siswa dituntut untuk memberikan perhatiannya pada setiap rangsangan yang diberikan dalam proses pembelajaran.

Dari penjelasan di atas, mengenai unsur belajar, teori belajar, dan prinsip belajar, dapat ditarik kesimpulan bahwa hasil belajar siswa dipengaruhi dari luar (eksternal) dan dari dalam diri (internal) siswa itu sendiri. Salah satu yang mempengaruhi hasil belajar dari luar diri siswa adalah media. Dalam proses pembelajaran yang merupakan proses komunikasi antara guru dan siswa, menurut Gagne dan Briggs (1979: 175) "media represent one component of delivery systems" yang artinya media merupakan salah satu komponen dari sistem penyampaian. Penyampaian disini adalah penyampaian pesan dari guru ke siswa berupa informasi atau pengetahuan dalam proses pembelajaran.

Media yang digunakan dalam penelitian ini adalah media video dan media gambar. Video yang merupakan salah satu jenis media audio visual yang mampu menampilkan gambar sekaligus suara dalam waktu bersamaan Menurut Smaldino, Lowther, dan Russell (2011: 404-405) tersedia untuk hampir seluruh jenis topik dan untuk seluruh jenis ranah pembelajaran, seperti ranah kognitif yang membantu siswa dapat mengamati reka ulang dramatis dari kejadian bersejarah dan perekaman aktual dari kejadian yang lebih belakangan karena membantu buku cetak dengan memperlihatkan proses, hubungan, dan teknik.

Sedangkan media gambar yang merupakan reproduksi asli dalam dua dimensi, yang berupa foto atau lukisan merupakan salah satu jenis media grafis yang termasuk dalam kategori media berbasis visual menurut Arsyad (2011: 91) memegang peranan penting dalam proses pembelajaran karena dapat memperlancar pemahaman dan memperkuat ingatan.

Scchraw, Crudden, dan Robinson (2013: 7) menyebutkan empat cara tampilan visual mempengaruhi belajar membantu siswa yaitu membantu siswa fokus pada informasi penting, mengurangi jumlah informasi dan mengaturnya dengan cara yang mengungkapkan hubungan yang paling penting dan proses yang kompleks antara konsep, instantiating informasi eksternal ke dalam model mental internal yang meningkatkan pemahaman informasi penting, dan mengurangi beban kognitif asing terkait dengan belajar sejumlah besar informasi yang kompleks.

Selain media pembelajaran, pada unsur belajar juga menyebutkan mengenai unsur kondisi subjek belajar, dimana kondisi subjek 
belajar juga menentukan kegiatan dan keberhasilan belajar. Contoh kondisi subjek belajar yang berasal dari dalam diri siswa adalah kemandirian belajar. Menurut Rohman (2009: 134-135) Siswa yang memiliki kemandirian belajar, termasuk ke dalam tipe kepribadian Autonomy. Tipe kepripadian Autonomy yaitu tipe kepribadan siswa yang ditandai dengan keinginan melakukan sesuatu secara mandiri, bertindak dan berinisiatif sendiri, tidak senang dibantu orang lain, juga tidak senang disuruh-suruh.

Pentingnya kemandirian belajar dinyatakan oleh Litschenberg dalam Martono (2007: iv) dalam ungkapan "When you have been obliged to discover by yourself, leaves a path in your mind which you can use again when need arises" yang artinya "Jika anda belajar dengan menemukannya sendiri, maka akan tertinggal suatu lorong di benak Anda yang dapat dimasuki lagi bilamana perlu bangkit". Pendapat tersebut menjelaskan bahwa dengan belajar secara mandiri akan didapat pemahaman konsep pengetahuan yang akan bertahan lama sehingga mempengaruhi pada pencapaian hasil belajar siswa.

Dari pembahasan di atas, penelitian ini membatasi diri pada faktor media pembelajaran, kemandirian belajar, dan hasil belajar IPA pada pokok bahasan hubungan sumber daya alam dengan lingkungan dan teknologi. Pada variabel media pembelajaran, dibatasi pada pemakaian media pembelajaran berbasis audiovisual berupa video dan media pembelajaran berbasis visual berupa gambar. Satu kelompok eksperimen memakai media video dan kelompok kontrol memakai media gambar.

\section{METODE}

Metode yang digunakan dalam penelitian ini adalah metode eksperimen dengan rancangan desain Treatment by level 2 X 2. Metode penelitian eksperimen dapat diartikan sebagai metode penelitian yang digunakan untuk mencari pengaruh perlakuan tertentu terhadap yang lain dalam kondisi yang terkendalikan. Metode eksperimen dengan variabel terikat adalah IPA pada pokok bahasan hubungan sumber daya alam dengan lingkungan dan teknologi (Y). Penelitian ini dilakukan perlakuan (treatment) untuk mencari pengaruh di antara dua variabel yaitu variabel perlakuan adalah media pembelajaran $\left(\mathrm{X}_{1}\right)$ dan variabel moderator adalah kemandirian belajar $\left(\mathrm{X}_{2}\right)$. Variabel perlakuan adalah media pembelajaran yang terdiri atas dua yaitu media video dan media gambar $\left(\mathrm{X}_{1}\right)$. Variabel moderator adalah kemandirian belajar ada dua yaitu kemandirian belajar tinggi dan kemandirian belajar rendah $\left(\mathrm{X}_{2}\right)$. 
Penelitian ini menggunakan media pembelajaran. Percobaan dilakukan kepada dua kelompok siswa yakni kelompok kemandirian belajar tinggi dan kelompok kemandirian belajar rendah mendapat perlakuan dengan pemberian media video dan kelompok kemmandirian belajar tinggi dan kelompok kemandirian belajar rendah mendapat perlakuan dengan media video. Adapun rancangan dalam penelitian ini terlihat pada Tabel 1 sebagai berikut:

Tabel 1: Rancangan Treatment by level 2 X 2

\begin{tabular}{ccc}
\hline Media Pembelajaran (A) & \\
\hline $\begin{array}{c}\text { Tinggi } \\
\text { (B1) }\end{array}$ & $\begin{array}{c}\text { Media Video } \\
\text { (A1) }\end{array}$ & $\begin{array}{c}\text { Media Gambar } \\
\text { (A2) }\end{array}$ \\
\hline $\begin{array}{c}\text { Rendah } \\
\text { (B2) }\end{array}$ & A1B1 & A2B1 \\
\hline
\end{tabular}

Sugiyono (2010:215) mengemukakan bahwa sampel adalah sebagian dari populasi. Teknik penarikan sampel dalam penelitian ini menggunakan simple random sampling yang menurut Soewadji (2012: 137) yaitu suatu cara atau teknik pengambilan sampel dari populasi dengan cara random atau acak sederhana.

Selanjutnya pada angket kemandirian belajar ditentukan kelompok atas dan kelompok bawah. Siswa dikategorikan ke dalam kelompok kemandirian belajar tinggi apabila skor berada pada rentang 27\% skor tertinggi. Kemudian siswa dikategorikan ke dalam kelompok kemandirian belajar rendah apabila skor kemandirian belajar berada rentang $27 \%$ terendah. $35 \times 27 \%=9$ sampel.

\section{HASIL}

Perbedaan hasil belajar IPA pada pokok bahasan hubungan sumber daya alam dengan lingkungan dan teknologi antara kelompok yang diberikan media video dan kelompok yang diberikan media gambar

Berdasarkan hasil analisis varian (ANAVA) pada taraf signifikan $\alpha=0,05$, didapat $\mathrm{F}_{\text {hitung }}=6,14>\mathrm{F}_{\text {tabel }}=4,11$. Dengan demikian $\quad \mathrm{F}_{\mathrm{o}}>\mathrm{F}_{\mathrm{t}}$, sehingga $\mathrm{H}_{0}$ ditolak, sehingga dapat disimpulkan bahwa secara keseluruhan, terdapat perbedaan pengaruh yang signifikan antara kelompok siswa yang diberikan media video dengan kelompok siswa yang diberikan media gambar terhadap hasil belajar IPA pada pokok bahasan 
hubungan sumber daya alam dengan lingkungan dan teknologi. Oleh karena itu, hasil belajar IPA pada pokok bahasan hubungan sumber daya alam dengan lingkungan dan teknologi yang diberikan media video $(\bar{X}=81,78$ dan $\mathrm{s}=8,25)$ lebih tinggi secara nyata dibandingkan yang diberikan media gambar $(\bar{X}=76$ dan $\mathrm{s}=$ $5,82)$.

Interaksi antara media pembelaajaran dengan kemandirian belajar terhadap hasil belajar IPA pada pokok bahasan hubungan sumber daya alam dengan lingkungan dan teknologi (INT A X B)

Hasil perhitungan ANAVA dapat diketahui bahwa nilai hasil pengujian hipotesis kedua yang disajikan dalam tabel ANAVA pada baris Interaksi A X B menunjukkan bahwa $\mathrm{H}_{0}$ ditolak berdasarkan nilai $\mathrm{F}_{\text {hitung }}=11,42>\mathrm{F}_{\text {tab }}(0,05: 1: 36)=4,11$ dengan demikian dapat diambil keputusan bahwa terdapat pengaruh interaksi yang signifikan antara media pembelajaran dan kemandirian belajar terhadap hasil belajar IPA pada pokok bahasan hubungan sumber daya alam dengan lingkungan dan teknologi.

Data hasil penelitian, diperoleh skor rata-rata hasil belajar IPA pada pokok bahasan hubungan sumber daya alam dengan lingkungan dan teknologi antara kelompok siswa yang memiliki kemandirian belajar tinggi yang diberikan media video adalah sebesar 87,56 dan kelompok siswa yang memiliki kemandirian belajar rendah yang diberikan media video adalah sebesar 76 . Untuk skor rata-rata hasil belajar IPA pada pokok bahasan hubungan sumber daya alam dengan lingkungan dan teknologi antara kelompok siswa yang memiliki kemandirian belajar tinggi yang diberikan media gambar adalah sebesar 75,11 dan kelompok siswa yang memiliki kemandirian belajar rendah yang diberikan media gambar adalah sebesar 76,89 .

Pada kelompok siswa yang memiliki kemandirian belajar tinggi, terdapat perbedaan hasil belajar IPA pada pokok bahasan hubungan sumber daya alam dengan lingkungan dan teknologi antara kelompok siswa yang diberikan media video dan kelompok siswa yang diberikan media gambar

Perhitungan analisis varians tahap lanjut dengan Uji Tukey adalah untuk membandingkan kelompok yang memiliki kemandirian belajar tinggi yang diberikan media video dan yang diberikan media gambar. Perhitungan Uji Tukey $\mathrm{A}_{1} \mathrm{~B}_{1}>\mathrm{A}_{2} \mathrm{~B}_{1}=$ $\mathrm{Q}_{\text {hitung }}=12,62$ lebih besar dari pada $\mathrm{Q}_{\text {tabel }}$ 0,05:4:36 $=4,07$ atau Qhitung $>$ Qtabel pada taraf signifikan $\alpha=0.05$, dengan demikian $\mathrm{H}_{0}$ ditolak dan hipotesis alternatif $\mathrm{H}_{1}$ diterima. Sehingga dapat ditafsirkan hasil belajar IPA pada pokok bahasan hubungan sumber daya alam dengan lingkungan dan teknologi antara kelompok siswa yang diberikan media video 
lebih tinggi dibandingkan dengan kelompok siswa yang diberikan media gambar.

Oleh karena itu, bagi siswa yang memiliki kemandirian belajar tinggi yang diberikan media video $(\bar{X}=87,56$ dan $\mathrm{s}=$ $6,14)$ lebih tinggi secara nyata dibandingkan yang diberikan diberikan media gambar $(\bar{X}$ $=76 \mathrm{~s}=5,65)$.

Pada kelompok yang memiliki kemandirian belajar rendah, terdapat perbedaan hasil belajar IPA pada pokok bahasan hubungan sumber daya alam dengan lingkungan dan teknologi antara kelompok siswa yang diberikan media video dan kelompok siswa yang diberikan media gambar

Perhitungan analisis varians tahap lanjut dengan Uji Tukey adalah untuk membandingkan kelompok yang memiliki kemandirian belajar rendah yang diberikan media video dan yang media gambar. Perhitungan Uji Tukey $\mathrm{A}_{1} \mathrm{~B}_{2}<\mathrm{A}_{2} \mathrm{~B}_{2}=Q_{\text {hitung }}=$ -0,90 lebih kecil dari pada $\mathrm{Q}_{\text {tabel } 0,05: 4: 36}=4,07$ atau $\mathrm{Q}_{\text {hitung }}<\mathrm{Q}_{\text {tabel }}$ pada taraf signifikan $\alpha=$ 0.05, dengan demikian $\mathrm{H}_{0}$ ditolak dan hipotesis alternatif $\mathrm{H}_{1}$ diterima. Sehingga dapat ditafsirkan hasil belajar IPA pada pokok bahasan hubungan sumber daya alam dengan lingkungan dan teknologi antara kelompok siswa yang diberikan media video lebih rendah dibandingkan dengan kelompok siswa yang diberikan media gambar.
Oleh karena itu, bagi siswa yang memiliki kemandirian belajar rendah yang diberikan media video $(\bar{X}=76$ dan $\mathrm{s}=5,65)$ lebih rendah secara nyata dibandingkan yang diberikan media gambar $(\bar{X}=76,89$ dan $\mathrm{s}=$ $6,25)$.

\section{PEMBAHASAN}

Perbedaan hasil belajar IPA pada pokok bahasan hubungan sumber daya alam dengan lingkungan dan teknologi antara kelompok yang diberikan media video dan kelompok yang diberikan media gambar

Hasil penelitian diperkuat dengan pendapat Smaldino, Lowther, dan Russell (2011: 7) yang membahas mengenai kemampuan yang dimiliki video seperti: (1) dapat membawa siswa ke berbagai tempat yang tidak mungkin bisa mereka kunjungi, (2) merupakan sarana utama untuk mendokumentasikan kejadian aktual, (3) membuat para siswa terpesona, (4) dapat mengkisahkan suatu cerita, (5) merekayasa perspektif temporal dan spasial, merekayasa waktu, (7) merekayasa tempat, (8) merekayasa waktu dan tempat dengan menggunakan animasi, dan (9) memahami konvensi. Sedangkan pada media gambar, siswa dari berbagai usia mudah memahami gambar, media gambar juga mudah ditemukan dalam buku cetak, dapat digunakan diseluruh fase pengajaran dari pengenalan topik hingga evaluasi, mewakili 
orang-orang, tempat, benda, dan konsep, dan bisa menjadi alat bantu yang efektif untuk belajar. Berdasarkan pendapat tersebut, disimpulkakan kemampuan media video yang dilengkapi dengan gerak dan suara dapat melengkapi kemampuan yang dimiliki media gambar sehingga media video lebih unggul dari media gambar. Hal ini berarti hipotesis penelitian secara keseluruhan adalah hasil belajar IPA pada pokok bahasan hubungan sumber daya alam dengan lingkungan dan teknologi yang diberikan media video lebih tinggi dibandingkan dengan kelompok siswa yang diberikan media gambar.

Interaksi antara media pembelajaran dengan kemandirian belajar terhadap hasil belajar IPA pada pokok bahasan hubungan sumber daya alam dengan lingkungan dan teknologi (INT A X B)

Hasil penelitian diperkuat dengan pendapat Carin (1964: 190) yang mengatakan bahwa "media also can significantly affect the quality of learning experience for pupils", yaitu media juga secara signifikan dapat mempengaruhi kualitas pengalaman belajar bagi siswa. Sedangkan pada kemandirian belajar, seperti pendapat Covey (1994: 38-39) yang mengatakan mengenai kemandirian adalah dimana seseorang itu tidak terus menerus memerlukan bantuan dari orang lain. Seperti dalam kemandirian belajar, siswa tidak terus menerus memerlukan bantuan guru dalam proses belajarnya, dimana guru berubah peran menjadi sebagai fasilitator saja. Jelas bahwa dengan adanya media pebelajaran akan membantu siswa yang memiliki kemandirian belajar sebagai sarana saat ia belajar sendiri. Hal ini berarti hipotesis penelitian terdapat interaksi antara media pembelajaran dengan kemandirian belajar terhadap hasil belajar IPA pada pokok bahasan hubungan sumber daya alam dengan lingkungan dan teknologi.

Pada kelompok siswa yang memiliki kemandirian belajar tinggi, terdapat perbedaan hasil belajar IPA pada pokok bahasan hubungan sumber daya alam dengan lingkungan dan teknologi antara kelompok siswa yang diberikan media video dan kelompok siswa yang diberikan media gambar

Hasil penelitian diperkuat berdasarkan pendapat Covey (1994: 38-39) sebelumnya, siswa yang memiliki kemandirian belajar tinggi dimana siswa tidak terus menerus bergantung pada orang lain pada kegiatan belajarnya jika dihubungkan dengan media pembelajaran video yang digunakan dalam proses pembelajaran, akan lebih menguntungkan karena tidak membutuhkan banyak peran dari guru saat penggunaannya. Media video akan memberikan pengalaman belajar langsung dan menarik dengan menggunakan dua indera sekaligus dan mendapat banyak pengalaman dalam belajar. 
Di lain pihak, siswa yang mengalami proses pembelajaran dengan menggunakan media gambar hanya melalui visual, dan dibantu dengan penjelasan guru secara verbal. Bagi siswa yang memiliki kemandirian belajar tinggi akan merasa kurang tertarik dikarenakan pengalaman yang didapatkan hanya sedikit. Hal ini berarti hipotesis penelitian kelompok yang memiliki kemandirian belajar tinggi yang diberikan media videolebih tinggi dibandingkan dengan yang diberikan media gambar terhadap hasil belajar IPA pada pokok bahasan hubungan sumber daya alam dengan lingkungan dan teknologi.

Pada kelompok yang memiliki kemandirian belajar rendah, terdapat perbedaan hasil belajar IPA pada pokok bahasan hubungan sumber daya alam dengan lingkungan dan teknologi antara kelompok siswa yang diberikan media videodan kelompok siswayang diberikan media gambar

Hasil penelitian diperkuat dengan melihat kebalikan dari pendapat Covey (1994: 38-39) sebelumnya, kemandirian belajar siswa yang rendah dihubungkan dengan media pembelajaran video yang lebih menguntungkan guru saat mengajar saat penyampaian materi, tidak menguntungkan bagi siswa yang memiliki kemandirian belajar rendah yang membutuhkan lebih banyak bantuan orang lain dalam proses belajar dibandingkan siswa yang memiliki kemandirian belajar tinggi.

Di lain pihak, siswa yang memiliki kemandirian belajar rendah yang menggunakan media pembelajaran gambar dalam proses pembelajaran, akan lebih menguntungkan baginya. Penggunaan media pembelajaran gambar pada siswa yang memiliki kemandirian belajar rendah yang cenderung mengikuti alur proses pembelajaran apa adanya sesuai dengan susunan yang ditentukan gurunya di sekolah akan lebih merasa terbantu dalam proses belajar karena sesuai dengan siswa yang memiliki kemandirian belajar rendah yang membutuhkan orang lain untuk membantunya dalam proses belajar. Siswa dengan kemandirian rendah lebih tertarik pada faktor eksternal berupa motivasi yang diberikan guru serta memiliki hubungan interpersonal yang lebih baik dengan orang-orang disekitarnya. Sehingga cenderung menerima informasi sesuai dengan apa yang diberikan saja.

Dengan begitu, terlihat bahwa kelompok yang memiliki kemandirian belajar rendah yang diberikan media gambar lebih tinggi dibandingkan dengan yang diberikan media video terhadap hasil belajar IPA pada pokok bahasan hubungan sumber daya alam dengan lingkungan dan teknologi. 


\section{SIMPULAN}

Penelitian ini menggunakan metode eksperimen yang melibatkan variabel bebas, yaitu media video dan media gambar dan kemandirian belajar, sedangkan sebagai variabel terikatnya adalah hasil belajar IPA pada pokok bahasan hubungan sumber daya alam dengan lingkungan dan teknologi siswa SD Negeri Karang Tengah 4 Tangerang.

Berdasarkan hasil analisis data, hasil pengujian hipotesis dan hasil pembahasan penelitian yang telah diperoleh dijelaskan beberapa kesimpulan sebagai berikut:

1. Media video memiliki pengaruh yang lebih tinggi nilainya dari media gambar terhadap hasil belajar IPA pada pokok bahasan hubungan sumber daya alam dengan lingkungan dan teknologi.

2. Terdapat interaksi antara media pembelajaran dan kemandirian belajar terhadap hasil belajar IPA pada pokok bahasan hubungan sumber daya alam dengan lingkungan dan teknologi.

3. Siswa yang memiliki kemandirian belajar tinggi, hasil belajar IPA meliputi pokok bahasan hubungan sumber daya alam dengan lingkungan dan teknologi antara kelompok siswa yang diajar media video lebih tinggi dari pada kelompok siswa yang diajar menggunakan media gambar.

4. Siswa yang memiliki Kemandirian belajar rendah, hasil belajar IPA meliputi pokok bahasan hubungan sumber daya alam dengan lingkungan dan teknologi antara kelompok siswa yang diajar menggunakan media video lebih rendah dari pada kelompok siswa yang diajar menggunakan media gambar.

\section{DAFTAR RUJUKAN}

Arsyad, Azhar. 2011. Media Pembelajaran. Jakarta: PT Raja Grafindo.

Cahyo, Agus. 2013. Panduan Aplikasi TeoriTeori Belajar Mengajar. Yogyakarta: DIVA Press.

Carin, A. A. 1964. Teacing Modern Science: Second Edition. Columbus: Charles E. Merrill Publishing Co.

Covey, S. R, 1994. alih bahasa oleh Budijanto. The Seven Habits of Highly Effective People. Jakarta: Binarupa Aksara.

Cronbach, Lee J. 1984. Essential of Psychological Testing; Fourth Edition. New York: Harper \& Row Publisher.

Gagne R. M \& Leslie J. Briggs. 1979. Principles of Instructional Design. United States of America: Holt, Rinehart and Winston.

Hamalik, Oemar. 2008. Perencanaan Pengajaran Berdasarkan Pendekatan Sistem. Jakarta: PT Bumi Aksara.

Martono, Koko, R. Eryanto, dan Firman Syah Noor. 2007. Matematika dan Kecakapan Hidup untuk SMA. Jakarta: Ganeca Exact.

Rohman, Arif. 2009. Memahami Pendidikan \& Ilmu Pendidikan. Yogyakarta: Laks Bang Mediatama. 
Rusman. 2012. Belajar dan Pembelajaran Berbasis Komputer: Mengembangkan Profesionalisme Guru Abad ke-21. Bandung: Alfabeta.

Schraw, Gregory, Matthew T. McCrudden \& Daniel Robinson. 2013. Learning Through Visual Displays. United States of America: Information Age Publishing, inc.

Smaldino, Saharon, E, Deborah L Lowther, \& James Russell. 2011. Instructional Technology and Media for Learning: Teknoogi Pembelajaran dan Media untuk Belajar Alih Bahasa oleh Arif Rahman. Jakarta, Kencana.
Soewadji, Jusuf. 2012. Pengantar Metodologi Penelitian. Jakarta: Mitra Wacana Media.

Sugiyono. 2010. Metode Penelitian Kuantitatif Kualitatif dan $R \& D$. Bandung: Alfabeta.

Sudjana, Nana. 2011. Penilaian Hasil Proses Belajar Mengajar. Bandung: PT Remaja Rosdakarya.

Yudhawati, Ratna dan Dany Haryanto. 2011. Teori-Teori Dasar Psikologi Pendidikan. Jakarta: Prestasi Pustakarya. 